\title{
St. Petersburg's experience in resolving of urban national conflicts
}

\author{
A. S. Matveevskaya ${ }^{1}$, S. N. Pogodin ${ }^{2}$ \\ ${ }^{1}$ St. Petersburg State University, \\ 7-9, Universitetskaya nab., St. Petersburg, 199034, Russian Federation \\ 2 Peter the Great St. Petersburg Polytechnic University, \\ 29, Politekhnicheskaya ul., St. Petersburg, 195251, Russian Federation
}

For citation: Matveevskaya A.S., Pogodin S. N. St. Petersburg's experience in resolving of urban national conflicts. Vestnik of Saint Petersburg University. Philosophy and Conflict Studies, 2019, vol. 35, issue 2, pp. 349-357. https://doi.org/10.21638/spbu17.2019.210

The second most popular Russian city with international migrants, St. Petersburg experiences severe difficulties with the integration of migrants, in particular the large scale of migration, imbalances in the relationships between the local population and migrants, the growth of a shadow market, and the lack of effective measures for integration. International migrants have their own system of values and lifestyles that cannot be easily integrated into the host society. The main aim of this study is to evaluate problems of integration and their effects on the city's social and cultural situation, and to analyze the potential of existing programs and developments oriented to reducing the intensity of national conflicts in St. Petersburg. The study uses the following methods: analysis of aspects of integration in the migration law of the Russian Federation, with a detailed overview of the integration situation in St. Petersburg; assessment of the efficiency of integration programs for international migrants implemented in the city; development of guidelines for enhancing the efficiency of the national integration policy based on positive practices. The results of the study show that St. Petersburg has potential for successful integration of migrants into the population: the activity of social organizations and involvement of city authorities provide an effective formula that requires but one more component: the wish of migrants themselves to adapt and to integrate into the local population.

Keywords: national conflicts, migrant integration, National Migration Policy Concept, integration potential of a city.

The Russian Federation has high economic potential, a decent quality of life, and well-developed inter-regional and foreign economic relations, which makes it an attractive destination for migrants from neighboring countries and beyond. By 2017, Russia is one of the leading countries in terms of the number of migrants (12 million people, $8 \%$ of the country's population). Each year, over 15 million people immigrate to the Russian Federation, and that rate is constantly growing [1]. Most are migrant workers who come to find work and improve their well-being. That said, new generations of migrants have limited knowledge of the Russian language and poor educational backgrounds and professional competence. About $88 \%$ of migrants come from neighboring countries [2]. According to the UN, most immigrants are from Tajikistan, Kazakhstan, Uzbekistan, and Ukraine [3]. Active migration flows are also typical for Germany, Lithuania, Latvia, and Estonia. In seven of nine federal districts, immigrants from CIS countries are prevalent.

(c) Санкт-Петербургский государственный университет, 2019 
For example, in the Northwestern Federal District, $46.5 \%$ of immigrants are from the EU. According to the Ministry of Internal Affairs of the Russian Federation, the most attractive federal districts for migrants are the Central Federal District, Northwestern Federal District, and the Southern Federal District [3]. The main purposes of coming to Russia are tourism $(23 \%)$ and work $(46 \%)$. In some regions, the share of tourists among foreigners is significantly higher: for example, in the Northwestern Federal District this share is $53 \%$.

The main document that determines Russian migration policy is the National Migration Policy Concept, adopted in 2012 and in force until 2025. According to this document, migration is an important means of increasing the country's population and accumulating human capital (National Migration Policy Concept of the Russian Federation until 2025 (approved by The President of the Russian Federation). July 10, 2018). Because of this, one of the main objectives of Russian migration policy is to attract highly qualified and skilled workers, entrepreneurs, and investors. At the same time, migration policy is aimed at continuously increasing the population, ensuring national security, combating illegal migration, facilitating the adaptation and integration of migrants, and establishing meaningful cooperation between immigrants and the host society.

Cultural and social adaptation of migrants falls within the competence of the Federal Agency for Ethnic Affairs (FAEA). The FAEA's main achievement in this field so far is the proposed law "On social and cultural adaptation and integration of foreign citizens in the Russian Federation", which sets forth a conceptual framework for interaction between authorities at all levels, involving non-profit organizations and civil society institutions [4]. This law is yet to be passed.

While issues of the legal status of foreign citizens fall within the competence of government authorities, the issues of adaptation, integration, and legal support are mainly covered by non-governmental organizations [5]. In Russia, the following non-governmental organizations have been operating for many years: Federation of Migrants of Russia, Forum for Migration Organizations, Civic Assistance Committee for Helping Refugees and Forced Migrants, Migration and Law Network, International Human Rights Assembly, Russian Red Cross Society, Partnership for Migration, Migration XXI Fund, etc. [6]. These organizations provide financial, legal, medical, and other support to migrants and conduct scientific research in the field of migration.

In the process of adaptation in the Russian Federation, immigrants face the following obstacles:

1) Limited knowledge of Russian. This is particularly relevant for younger immigrants, who received their education after the collapse of the Soviet Union. At the same time, the law requires those who want to obtain a temporary or permanent residence permit or work permit to confirm basic knowledge of the Russian language by presenting academic credentials issued in the USSR before September 1, 1991, or by passing an exam.

2) The need to adopt a new culture, and ignorance of customs and traditions of the host society and fundamentals of Russian legislation.

3) Limited access to the labor market: the need to pass exams in Russian language, history, and Russian law, the high cost of patent execution, and long bureaucratic procedures. As a result, many immigrants work illegally and thus without any legal or social protection. It is also fair to say that migrant labor is used inefficiently. 
The starting position of migrants in the Russian Federation does not correspond to their professional competence or fields of expertise, i. e. their qualification mobility is downward [7].

4) Lack of access to social services. Medical services can be provided free of charge only if there is a danger to life. Only foreign citizens with a permanent residence permit are recognized as fully equal to Russian citizens in terms of social support, including access to education and health services. Until then, immigrants are on their own and can rely only on the support of charitable organizations. Another issue is the access of migrant children to secondary education: parents must be registered at their place of residence for their children to be admitted to school; for lack thereof, many children do not attend school at all.

5) Negative attitude towards migrants by the host society: according to a poll conducted by the Levada Center, every second Russian citizen has a negative attitude towards a certain category of migrant workers, while $32 \%$ of respondents consider them to be poorly educated individuals only capable of menial work [8].

Consequently, measures taken at the federal and regional level are aimed at solving these problems.

According to the Ministry of Internal Affairs of the Russian Federation, the Northwestern Federal District is the second most popular destination for migrants after the Central Federal District: in 2017, it hosted 3,156,958 foreigners, most of them tourists $(1,486,087)$ or expats $(788,430)$ [9]. Thus, migrant workers are a majority in the Northwestern Federal District, most of them coming from countries with a visa-free regime. Measures aimed at the adaptation and integration of immigrants are implemented at the level of executive authorities of the constituent entities of the Russian Federation - governments and administrations - in accordance with the National Migration Policy Concept adopted at the federal level.

St. Petersburg and the Leningrad region account for the most significant influx of immigrants in the Northwestern Federal District. Most immigrants come from Uzbekistan, Ukraine, Tajikistan, Armenia, Azerbaijan, Kyrgyzstan, and Moldova. In 2017, $2,696,542$ foreign subjects registered with the migration registration bodies, 15,704 received a temporary residence permit, and 14,504 were granted a permanent residence permit [9].

Today, employment by industry is as follows in percentages: $20 \%$ in theservice industry, $70 \%$ in construction and utility work, and less than $10 \%$ in manufacturing, trade, transport industry, and hotel and restaurant businesses. Note that these data pertain only to formally employed foreign subjects. We do not know how the statistics would look with allowance for illegal migration, the share of which experts believe to be significant. We also note the level of qualifications of foreign migrants. Immigrants that arrive from CIS countries today often do not have even secondary education, let alone higher education; their professional training is lacking, and their knowledge of the Russian law, language, and culture is insufficient. Even worse, international migrants adhere to their own customs, ignoring local traditions [10]. All this takes its toll on the ethnic and religious situation in St. Petersburg, which results in an increasing number of conflicts between migrants and the local population. 
There is also an increasing concern about the higher crime rate instigated by foreign migrant workers in all big Russian cities, including St. Petersburg. The Ministry of Internal Affairs claims that in 2015, foreign citizens and stateless persons in Russia committed 46.4 thousand crimes, which is $4.4 \%$ more than in January-December 2014, and 40.3 thousand of these crimes $(+4.9 \%)$ were committed by residents of the CIS countries, accounting for $86.9 \%$ [11]. St. Petersburg suffered 30 acts of terrorism in 2010-2017, with the highest number registered in 2016 (13 crimes). Over the same period (20102017), there were also 109 acts of extremism. According to the Head of the Main Directorate of the Ministry of Interior Affairs in St. Petersburg and the Leningrad region, three thousand crimes committed by migrants were officially solved in 2014. "This accounts for $11 \%$ of all solved crimes and includes 33 murders, 15 rapes, 49 cases of causing bodily harm" [12].

All these trends indicate two things. First, international migration, including labor migration, will not stop in the near future, since Russian foreign economic policy does not account for a reduction in the flow of migrants, making this a fact of today's life. The second point is that migration needs to be controlled and systematized. In this regard, integration of foreign migrants into the host society could be the most promising solution, especially considering that St. Petersburg has all the prerequisites for its development.

Issues of migrant adaptation in St. Petersburg and the Leningrad region are currently handled mainly by the Governor's International Relations Council, St. Petersburg State Committee for International Relations and Migration Policy Implementation, St. Petersburg State Advisory Council for Migration Policy Implementation, St. Petersburg State Religious Organization Relations Department, many national and cultural organizations (autonomies, communities, centers), and the Spiritual Administration of Muslims of St. Petersburg and Northwestern region of Russia.

In 2014, a government program for creating conditions to ensure social consensus in St. Petersburg for 2015-2020 was developed, which involves implementing the National Migration Policy Concept and harmonizing inter-ethnic relations. These measures include, among other things, establishing information offices in places of migrant arrival, publication of information materials about legislative regulations of the Russian Federation, rules of conduct, traditions, cultural activities, organization of educational and cultural activities, and initiative competitions. For example, Russian language courses for immigrants are organized in various districts of St. Petersburg [13].

In 2017, the share of migrant workers in St. Petersburg, with the exception of highly qualified specialists who passed exams in Russian language, history, and law, was $92.4 \%$. In the Leningrad region, the project "Migrant School. Welcome to the Leningrad Region" has been set up. Within the framework of this project, thematic booklets Welcome to the Leningrad Region and Migrant's Handbook have been issued, and seminars for heads of companies and organizations that hire foreign citizens are conducted, providing insight into the specifics of migration and labor legislation. There is also a specialized website for immigrants that contains useful information about rules of stay in the Russian Federation, necessary documents, accommodation, and life in St. Petersburg [14].

Furthermore, an initiative competition is held in St. Petersburg annually, where initiatives are aimed at inculcating a positive attitude to immigrants and their adaptation. St. Petersburg House of Nationalities, established by the city government, also organizes cultural events to facilitate immigrant adaptation, such as St. Petersburg Ball of Nationali- 
ties, We Are Together Gala Concert, St. Petersburg Ethnic Cuisine Festival, Multinational St. Petersburg Youth Forum, International Mother Language Day, Slavic Literature and Culture Day, and Russia Day.

The activities of the PSP Charity Foundation for the Support and Development of Educational and Social Projects should also be mentioned. The Foundation helped create an information portal for immigrants. In 2018, it published a handbook for migrant workers written by migrants with years of experience. The Foundation also holds regular training sessions to help immigrants and their families adapt, and publishes booklets and brochures for migrants in Tajik and Uzbek language. It has many successful projects and initiatives to its name, not only in the Leningrad region, but also in the Murmansk and Arkhangelsk regions and in the Republic of Karelia.

St. Petersburg initiated the publication of such legal brochures as Migrant Worker's Pocket Book and Migrant Worker's Handbook. The latter has been funded by the personal finances of a single entrepreneur and submitted for development to the Working Migrants from Central Asia Fund. Experts of the Fund then compiled a legal handbook with detailed information on which documents and certificates should be obtained before coming to St. Petersburg, how to officially register one's stay in the city, where to find accommodation and employment, and how to get medical and legal assistance. The Handbook also includes an Uzbek-Russian phrasebook, a list of useful addresses and phone numbers, and a St. Petersburg city and metro map.

The St. Petersburg Committee for International Relations and Migration Policy Implementation has developed the so-called Sub-Program 5 within the framework of the program for creating conditions to ensure social consensus in St. Petersburg for 20152020 (Government program for creating conditions to ensure social consensus in Saint Petersburg (as amended on February 7, 2018)). Sub-Program 5 proposes the following measures to create favorable conditions for migrants' social and cultural adaptation: organizing events to facilitate the integration of migrants into society; educating employees of St. Petersburg government bodies in migration, adaptation, and integration of migrants; combating extremism and xenophobia; establishing accommodation and employment agencies for migrants; and conducting annual sociological surveys in order to improve the approach to integration, etc.

The St. Petersburg Committee for International Relations and Migration Policy Implementation is also responsible for creating a series of videos called "St. Petersburg A City for Everyone" [15]. The main goal of this project is to facilitate the adaptation and integration of migrants, to set up a meaningful dialogue between migrants and the local population, and to provide insight into the culture, history, and traditions of St. Petersburg. Each video is dedicated to immigrants and the way they adapt to life in the city and make it legal. The authors use accessible language to explain the sequence of actions that a migrant has to go through, present successful cases of cooperation between employers and legal foreign workers, and tells the stories of those who have achieved certain success in St. Petersburg, with the focus on real people and their lives. Public and political figures of St. Petersburg, academics and scientists, heads of executive bodies, and members of the Directorate for Migration Affairs in St. Petersburg and the Leningrad region all played their roles as consultants or co-authors for the project.

The St. Petersburg branch of the Russian Red Cross Society also holds events aimed at the adaptation and integration of migrants and refugees. For example, the St. Petersburg 
Migrant Integration and Adaptation Information Center provides free Russian language and computer knowledge courses and prepare children with poor knowledge of Russian language for school [16]. Moreover, the Red Cross gives public lectures on issues of migration and organizes winter and summer schools on migration to attract people's attention to the problems of migrants. Thus, we can say that St. Petersburg and the Leningrad region make persistent efforts to facilitate migrant adaptation.

We can also see that most measures are aimed at eliminating the language barrier and bolstering exchange of cultural experiences. Information portals are available on the Internet to provide migrants with all necessary information about their legal status and rules of labor activity and conduct in Russian society. One major disadvantage of these websites is the lack of translation into migrants' native languages. Additionally, more active measures should be taken to make healthcare and education more accessible for immigrants and their children and to combat xenophobia and discrimination, particularly in the labor market. For now, the battle against xenophobia is fought mainly at the level of civil society. Vivid examples of this process include the March Against Hatred and social campaign "I Don't Want to Hate!" that took place in St. Petersburg, "Say No to Racism!" campaign in Petrozavodsk, and a march against racism and xenophobia in Karelia.

Considering the positive practices for solving problems of immigrants' socio-economic adaptation and taking into account the migration situation in Russia, we propose the following recommendations aimed at improving the effectiveness of the adaptation policy for foreign citizens:

1) Russia needs to establish a special institution to deal solely with issues of migration, adaptation, and integration of migrants, and to develop a Migration Code that would systematize existing legislation. This would improve effectiveness of the migration policy. Furthermore, we recommend formalizing the foundations of the national migration adaptation policy. FAEA's proposed law "On social and cultural adaptation and integration of foreign citizens in the Russian Federation" can be one example;

2) To expedite adaptation in a new society, we recommend developing a program of free language courses and courses in Russian law. Attending these courses can be made a mandatory requirement for obtaining a work permit or patent;

3) We also recommend developing a certification centers to assess migrants' level of professional knowledge and training. This would help attract qualified specialists to Russia, train personnel in required specializations, and use migrants' potential more efficiently;

4) Uniform distribution of migrant flows across Russia's regions requires centralized recruitment of foreign citizens with allowance for regional demand for labor and the ability of regions to accommodate immigrants. For this purpose, we recommend establishing a network of specialized centers in CIS countries and creating a database of vacancies for employers who need foreign workers;

5) It seems viable to expand the network of Russian language and culture centers to promote them in countries where most migrants come from: Tajikistan, Kazakhstan, Uzbekistan, Kyrgyzstan;

6) To facilitate migrant adaptation, we recommend involving non-profit organizations and civil society; 
7) Significant effort should be invested in changing the negative attitude towards migrants and negative stereotypes about them through media and non-profit organizations, informing the population about the culture and traditions of migrants' native countries;

8) As part of implementing migration policy, it is still necessary to combat illegal migration, which is a threat to national security, and corruption in government institutions that work with migrants.

These measures should help facilitate the socio-economic adaptation of migrants, reduce social tension, ensure national consent, use the potential of migrant workers efficiently, improve the efficiency of migration management, develop cross-cultural communication skills in migrants and the host society, and partially solve economic and demographic problems of the Russian Federation.

\section{References}

1. Official website of the Ministry of Internal Affairs of the Russian Federation (2017), "Selected indicators of the migration situation in the Russian Federation in January-December 2017 sorted by country and region", available at: https://xn--blaew.xn--plai/Deljatelnost/statistics/migracionnaya/item/12162171/ (accessed 15 August 2018).

2. Makhmudova, M., and Koroleva, A. (2017), "Mezhdunarodnye migratsionnye protsessy v rossiiskoi ekonomike: analiz sovremennykh tendentsii" [International migration processes in the Russian economy: analysis of modern trends], in Vestnik Omskogo universiteta, ser. Economics, no. 2 (58), pp. 41-53. (In Russian)

3. Official website of the United Nations Population Division, Department of Economic and Social Affairs (2018), available at: http://www.un.org/en/development/desa/population/migration/data/estimates2/ estimates17.shtml (accessed 17 July 2018).

4. Official website of the Federal Agency for Ethnic Affairs (2018), available at: http://fadn.gov.ru/ news/2017/05/12/3216-fadn-rossii-podgotovlen-proekt-federalnogo-zakona-o-sotsialnoy-i-kulturnoy-adaptatsii-i-integratsii-inostrannyh-grazhdan-v-rossiyskoy-federatsii (accessed 20 August 2018).

5. Matveevskaya, A. (2015), "Sovremennye tendentsii migratsionnoi politiki Evropeiskogo Soiuza" [Modern trends in the migration policy of the European Union], in Nauka Krasnoiar'ia, no. 6 (23), pp. 2939. (In Russian)

6. Paskachev, A., Volokh, V. and Suvorova, V. (2017), Gosudarstvennaia migratsionnaia politika RF $v$ novykh usloviiakh [National migration policy of the Russian Federation: a monograph], Institute of Migration and Interethnic Relations, Litera Publ., Yaroslavl. (In Russian)

7. Varshavskaya, E., and Denisenko, M. (2014), "Mobil'nost' inostrannykh rabotnikov na rossiiskom rynke truda" [Mobility of foreign workers in the Russian labor market], in Sotsiologicheskie issledovaniia, no. 4, pp. 78-91. (In Russian)

8. VEDOMOSTI (2018), "The attitude towards migrants in Russia is getting worse - Levada-Center", available at: https://www.vedomosti.ru/politics/articles/2017/04/28/687871-otnoshenie-migrantam-uhudshaetsya (accessed 24 August 2018).

9. Official website of the Presidential Plenipotentiary Envoy to the Northwestern Federal District (2018), available at: http://szfo.gov.ru/district/ (accessed 24 April 2018).

10. Matveevskaya, A., and Pogodin, S., (2018), "Integration of migrants as a way to diminish proneness to conflict in multinational communities", in Vestnik of Saint Petersburg Univehsity, ser. Philosophy and Conflict studies, vol. 34, no. 1, pp. 108-114.

11. Official website of the Ministry of Internal Affairs of the Russian Federation (2015), "The state of crime", available at: www.мвд.pф/folder/101762/item/7087734/ (accessed 13 August 2018).

12. Politics today (2018), "The number of crimes committed by migrants in Saint Petersburg is growing", available at: www.polit.info/88820-chislo-prestupleniy-sovershennyih-migrantami-v-peterburge-rastet (accessed 14 August 2018).

13. Official website of the Administration of Saint Petersburg, free Russian language courses for foreign citizens from the CIS countries and beyond (2018), available at: https://www.gov.spb.ru/gov/otrasl/ kmormp/news/53531/ (accessed 20 July 2018). 
14. Welcome to Saint Petersburg (2018), available at: http://migrantinfo.spb.ru/ (accessed 22 August 2018).

15. Official website of the Administration of Saint Petersburg (2017), "Saint Petersburg - A city for Everyone", available at: https://www.gov.spb.ru/gov/otrasl/kmormp/videoroliki-peterburg-gorod-otkrytyjdlya-vseh/ (accessed 14 August 2018).

16. Official website of the Russian Red Cross Society (2018), "Saint Petersburg Migrant Integration and Adaptation Information Center", available at: http://www.spbredcross.org/pages/sankt-peterburgskij-informatsionnyj-tsentr-po-voprosam-integratsii-i-adaptatsii-migrantov (accessed 23 August 2018).

Received: June 24, 2018

Accepted: February 7, 2019

Author's information:

Anna S. Matveevskaya — PhD, Senior Lecturer; annamatveevskaya@mail.ru

Sergey N. Pogodin - Dr. Sci. in History, Professor; pogodin56@mail.ru

\title{
Опыт Санкт-Петербурга в разрешении межнациональных конфликтов в городе
}

\author{
А. С. Матвеевская ${ }^{1}$, С. Н. Погодин ${ }^{2}$ \\ ${ }^{1}$ Санкт-Петербургский государственный университет, \\ Российская Федерация, 199034, Санкт-Петербург, Университетская наб., 7-9 \\ ${ }^{2}$ Санкт-Петербургский политехнический университет Петра Великого, \\ Российская Федерация, 195251, Санкт-Петербург, Политехническая ул., 29
}

Для цитирования: Matveevskaya A. S., Pogodin S. N. St. Petersburg's experience in resolving of urban national conflicts // Вестник Санкт-Петербургского университета. Философия и конфликтология. 2019. Т. 35. Вып. 2. С. 349-357. https://doi.org/10.21638/spbu17.2019.210 (In English)

Санкт-Петербург как второй по популярности российский город среди международных мигрантов испытывает серьезные миграционные и, как следствие, интеграционные трудности. К ним относятся массовый характер миграции, дисбаланс во взаимоотношениях между местными жителями и мигрантами, рост теневого рынка и отсутствие действенных интеграционных мер. Международные мигранты - носители иной системы ценностей и образа жизни, достаточно трудно включаются в принимающее общество, и в связи с этим считается весьма перспективным проанализировать интеграционный потенциал города, который будет соответствовать потребностям петербуржцев и международных мигрантов. Целью данного исследования является оценка интеграционных проблем, их влияние на социальную и культурную обстановку в городе, а также анализ перспективности существующих программ и разработок, направленных на снижение межнациональной конфликтности в Санкт-Петербурге. Основными методами исследования являются: анализ - рассмотрены аспекты интеграции в миграционном законодательстве Российской Федерации, а также проведен детальный обзор интеграционной обстановки в Санкт-Петербурге; обобщение - в процессе рассмотрения множества проблем интеграционного характера был сделан общий вывод о несостоятельности и неразвитости политики интеграции как на региональном, так и на общегосударственном уровне; оценка успешности применяемых в городе интеграционных программ для международных мигрантов; разработка рекомендаций по повышению эффективности интеграционной политики в стране с учетом положительных практик в этой области. Результаты исследования показали, что Санкт-Петербург имеет достаточный потенциал для того, чтобы успешно интегрировать мигрантов в общество: деятельность общественных организаций и заинтересованность город- 
ских властей - практически действующая формула, однако необходим еще один компонент - желание самих мигрантов адаптироваться и интегрироваться в общество с учетом местных особенностей.

Ключевые слова: межнациональные конфликты, интеграция мигрантов, Концепция государственной миграционной политики, интеграционный потенциал города.

Статья поступила в редакцию 24 июня 2018 г.; рекомендована в печать 7 февраля 2019 г.

Контактная информация:

Матвеевская Анна Сергеевна - канд. геогр. наук, ст. преп.; annamatveevskaya@mail.ru Погодин Сергей Николаевич - д-р ист. наук, проф.; pogodin56@mail.ru 